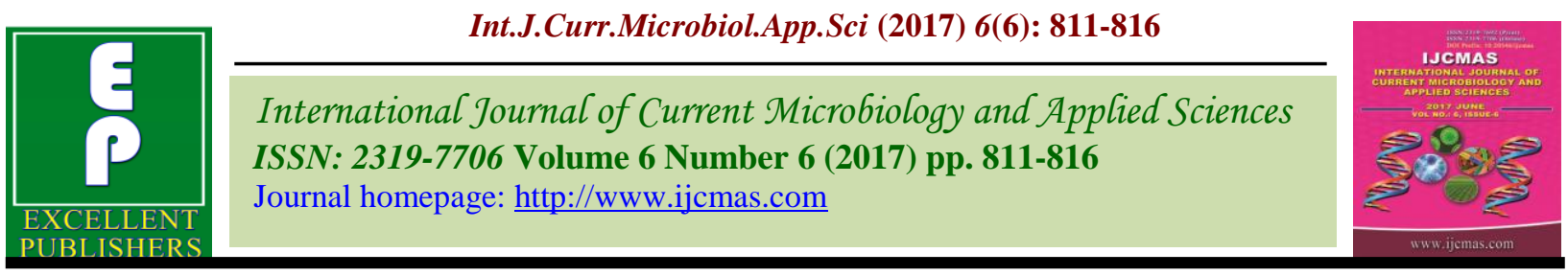

Original Research Article

https://doi.org/10.20546/ijcmas.2017.606.095

\title{
Grain Yield and Morpho-Physiological Traits in Stripe Rust Resistant Lines of Wheat (Triticum Aestivum L.)
}

\author{
Sandeep Kumar Bangarwa* and Tuhina Dey
}

Division of Plant Breeding and Genetics, Sher-e-Kashmir University of Agricultural sciences and Technology of Jammu Chatha, Jammu-180009, Jammu and Kashmir, India

*Corresponding author

\section{A B S T R A C T}

The present investigation was carried out with the objective of enhancement for stripe rust resistance in the adapted varieties of wheat grown under timely sown irrigated conditions.

\section{Keywords}

Stripe rust resistant lines, Parents, Hybrids and Parent's v/s Hybrids.

\section{Article Info}

Accepted:

14 May 2017

Available Online:

10 June 2017
The material for the experiment consisted of six stripe rust resistant lines and three adapted varieties of wheat crossed in Line x Tester design during off season of 2013 at Dalang Maidan, Lahaul Spiti, and Himachal Pradesh. The F1s were grown during rabi 2013 at Research Farm, Division of Plant Breeding and Genetics, SKUAST Chatha, Jammu. The results revealed that the variances due to parents, hybrids and parents v/s hybrids were significant. The parent with the minimum plant height was DWR 19 (79.73 cm.), maximum number of effective tillers per plant was DPW 621-50 (14 tillers), minimum days to $50 \%$ flowering was DWR 41 at 61 days, maximum grains per spike was PBW 550 (54.67) and minimum days to maturity were DWR 46 and PBW 550 at 135 days. Amongst the crosses, minimum plant height was observed in DWR 46 x RSP 561 $(49.67 \mathrm{~cm})$, maximum number of tillers was IBWSN1175 x PBW 550 with 16.67 tillers, maximum spike length with IBWSN1175 x RSP 561 and DWR 19 x RSP 561 had spike length measuring $14.17 \mathrm{~cm}$, minimum days to 50\% flowering were IBWSN1047 x PBW 550 and DWR 41 x RSP 561 with 60 days, maximum value for this trait were IBWSN1175 x PBW 550 (56.67), maximum grain yield per plant was IBWSN1175 x PBW 550.

\section{Introduction}

The spectrum of biotic and abiotic stresses affecting wheat crop is increasingly becoming unpredictable and there is an alarming need for the preparedness towards overcoming these stresses. The rusts (stripe, leaf and stem) are the most important biotic factors among the all other biotic factors that reduce wheat production significantly. The wheat rusts are caused by three species of the fungal genus Puccinia; stripe rust or yellow rust is caused by Puccinia striiformis f.sp. tritici; leaf rust by Puccinia triticina and stem rust by Puccinia graminis f.sp. tritici. Stripe rust is principally a disease of wheat grown in cooler climates $\left(2^{\circ} \mathrm{C}-15^{\circ} \mathrm{C}\right)$, and generally associated with higher elevations, northern latitudes or cooler years. Free water on the leaves and temperatures of $0^{\circ} \mathrm{C}$ to $25^{\circ} \mathrm{C}$ are required for spore germination.

Development of resistant varieties is the ecologically safe and sustainable means to overcome the threat. Several resistant varieties have been bred till now, however the resistances of most varieties are short-lived due to evolution of new races of the pathogen. 
Long term robust resistance based upon the 'stacking' of different sources of genes with a proven level of durability offers the best solution. The effects of moderate resistances can be additive and combined to provide near immunity (Angus and Fenwick, 2008). Globally the wheat breeding efforts are on accumulating minor genes for attaining desired level of resistance in a variety. This is a challenging task as it requires identification of parents with minor genes, crossing them in specific schemes following back cross and maintaining desirable population size and selection of desirable genotypes from segregating populations.

Conventional breeding aided by genome analysis and other marker-aided gene pyramiding provide powerful alternative to facilitate gene deployment and gene pyramiding for quick release of rust resistant cultivars. Numerous genes conferring resistance to wheat rusts have been identified and used in bread wheat improvement programmes. A number of stripe rust resistant genes have been identified and deployed in the popular varieties through breeding (Chen et al., 1995; Bariana and McIntosh, 1993; Payne et al., 1989; Hart et al., 1993; McIntosh and Arts, 1995). However, several of these genes have been rendered ineffective due to emergence of new virulent races. With this background the present study was conducted towards the isolation of pure lines from the progenies of heterotic F1s. These heterotic F1s in combination with the resistant gene(s) could lead to the enhancement of stripe rust resistance in wheat.

\section{Materials and Methods}

The material for the experiment consisted of six stripe rust resistant lines and three adapted varieties of wheat crossed in Line into Tester design during off season 2013 at Dalang Maidan, Lahaul Spiti. The details of the material used and methods adopted during the course of investigation are listed in table 1 .

The six female lines were crossed with three male testers to generate 18 single crosses. The F1s were grown during rabi 2013 at Research Farm, Division of Plant Breeding and Genetics, SKUAST Chatha, Jammu. Progeny from all the twenty seven combinations ( 9 parents and 18 hybrids) were sown in during off season 2014 at Dalang Maidan, Lahaul Spiti. Standard agronomic practises were followed and data was recorded on 3 random competitive plants of through standard procedure each progeny.

The statistical analysis was conducted over mean of ten selected plants for each entry in each replication. The variation between the progenies (parents and crosses) for the different characters was partitioned based on the following model.

$X i j k=\mu+g i j+r k+e i j k$

Where,

Xijk =Observation recorded on the ijth genotype sown in the Kth replication.

$\mu=$ General mean,

gij=the effect of the ijth genotype.

$\mathrm{rk}=$ the effct of the kth replication and

eijk= the error component associated with Xijkth observation.

The assumptions of modal are:

All the observations should be independent.

Error involved in population should be normally and independently distributed with mean zero and variance 2 . 
The different effects in the model should be additive.

The variation due to the progenies was further partitioned into parts due to 'parents', 'hybrids' and 'parents versus hybrids' to see individually the variation of these groups and to detect overall heterosis. The progenies variance (observed mean variance) were compared against error by $\mathrm{F}$, test at (p-1), ( $\mathrm{r}$ 1) (p-1) degrees of freedom at $P=0.05$ and 0.01. The estimates of standard error of difference for two progeny means were obtained by the following formula:

S.E. of difference $=\sqrt{\frac{2 M e}{r}}$

The critical difference for comparing any two progeny means were computed by multiplying the standard error of difference with the $t$ values at error degree of freedom at $\mathrm{P}=0.05$ and $\mathrm{P}=0.01$ (Table 2).

\section{Results and Discussion}

The analysis of variances and means have been presented in tables 3 and 4, respectively. The variances due to parents, hybrids and parents v/s hybrids were significant. The parent with the minimum plant height was DWR 19 (79.73 cm.) followed by DWR- 46 (80.67 cm.) Amongst the crosses, minimum plant height was observed in DWR $46 \times$ RSP $561(49.67 \mathrm{~cm})$ followed by DWR $46 \times \mathrm{DPW}$ 621-50 $(61.50 \mathrm{~cm})$ and DWR 46 x PBW 550 at $64.13 \mathrm{~cm}$. The line with maximum number of effective tillers per plant was DPW 621-50 (14 tillers) followed by RSP 561 and PBW 550 with 12 tillers per plant. The cross with maximum number of tillers was IBWSN1175 x PBW 550 with 16.67 tillers followed by DWR 41 x PBW 550 (13 tillers). The range for tiller number in the crosses varied from 7 to 16 with the cross DWR $46 \times$ RSP 561 having tiller number as low as 7 . The variances for this trait were significant for parents, hybrids and parent's v/s hybrids. The range for this trait in the parents varied from 9.97 to $12.90 \mathrm{~cm}$ while that for the crosses ranged from 09.27 to $14.17 \mathrm{~cm}$.

The parent with the maximum spike length was RSP 561 at $12.9 \mathrm{~cm}$ while the cross IBWSN1175 x RSP 561 and DWR 19 x RSP 561 had spike length measuring $14.17 \mathrm{~cm}$. The line with the minimum days to $50 \%$ flowering was DWR 41 at 61 days followed by IBWSN1175 at 62 days. The cross with minimum days to $50 \%$ flowering was IBWSN1047 x PBW 550 and DWR 41 x RSP 561 with 60 days. The range for this trait in the crosses varied from 60-70 days. The variances for this trait were significant for parents, hybrids and parent's v/s hybrids. The line with the maximum grains per spike was PBW 550 (54.67) followed by IBWSN1175 (54.33) while the cross which had maximum value for this trait was IBWSN1175 x PBW 550 (56.67) followed by IBWSN1047 x PBW 550 (55.0). The parents with the minimum days to maturity were DWR 46 and PBW 550 at 135 days.

The range in the parents was between 135 to 145 days while crosses exhibited wide variation for this trait between 118 to 135 days. The variances for grain yield per plant were significant for hybrids and parents v/s hybrids. The parent with the maximum grain yield per plant was DPW 621-50 and IBWSN1175 with a yield of $20 \mathrm{gm}$. The range of grain yield in the crosses varied from 10.00 to $23.00 \mathrm{~g}$. The cross with maximum grain yield per plant was IBWSN1175 x PBW 550 while that with minimum grain yield was IBWSN1047 x RSP 561. 
Table.1 Name of parents, their pedigree and source of collection

\begin{tabular}{|c|c|c|c|}
\hline S. No. & Name of parents & Pedigree & Source \\
\hline \multicolumn{4}{|l|}{ FEMALES } \\
\hline 1. & $1047,44^{\text {th }}$ IBWSN & $\begin{array}{l}\text { BAV92//IRENA/KAUZ/3/HUI } \\
\text { TES/4/DOLL }\end{array}$ & $\begin{array}{l}44^{\text {th }} \text { IBWSN, } \\
\text { CIMMYT }\end{array}$ \\
\hline 2. & $1174,44^{\text {th }}$ IBWSN & $\begin{array}{l}\text { (C.80.1/B*BATAVIA//I*WBLL } \\
\text { 1/5/REH/HARE//2*BCN/...) }\end{array}$ & $\begin{array}{l}4^{\text {th }} \text { IBWSN, } \\
\text { CIMMYT }\end{array}$ \\
\hline 3. & $1175,44^{\text {th }}$ IBWSN & $\begin{array}{l}\text { (SERI.18*2/3/KAUZ*2/BOW// } \\
\text { KAUZ/4/CROC) }\end{array}$ & $\begin{array}{l}44^{\text {th }} \text { IBWSN, } \\
\text { CIMMYT }\end{array}$ \\
\hline 4. & DWR 19 & IC 296783/ IC 253000 & DWR, Karnal \\
\hline 5. & DWR 41 & IC 296436 & DWR, Karnal \\
\hline 6. & DWR 46 & IC 296446 & DWR, Karnal \\
\hline \multicolumn{4}{|l|}{ MALES } \\
\hline 1. & RSP-561 & HD 2687/Ae. crassa//HD 2637 & $\begin{array}{l}\text { SKUAST, } \\
\text { Jammu }\end{array}$ \\
\hline 2. & PBW-550 & WH594/RAJ3858/W485 & PAU, Ludhiana \\
\hline 3. & DPW-621-50 & $\begin{array}{l}\text { KAUZ//ALTAR84/AOS/3/MIL } \\
\text { AN/KAUZ/4/ HUITES }\end{array}$ & DWR, Karnal \\
\hline
\end{tabular}

Table.2 The analysis of variances leads to the following break-up of the total variation

\begin{tabular}{|l|c|l|l|}
\hline \multicolumn{1}{|c|}{ Source of Variation } & d.f. & \multicolumn{1}{c|}{ Sum of squares } & \multicolumn{1}{c|}{ Mean squares } \\
\hline Replications & $\mathrm{r}-1$ & $\mathrm{~S}_{\mathrm{r}}=\sum \mathrm{R}^{2} / \mathrm{p}-(\mathrm{Sr} . .)^{2 / \mathrm{N}}$ & $\mathrm{M}_{\mathrm{r}}=\mathrm{S}_{\mathrm{r}} /(\mathrm{r}-1)$ \\
\hline Parents & $\mathrm{k}-1$ & $\mathrm{~S}_{\mathrm{k}}=\sum \mathrm{K}^{2} / \mathrm{r}-(\mathrm{Sk} . .)^{2 / \mathrm{rk}}$ & $\mathrm{M}_{\mathrm{k}}=\mathrm{S}_{\mathrm{k}} /(\mathrm{k}-1)$ \\
\hline Hybrids & $\mathrm{h}-1$ & $\mathrm{~S}_{\mathrm{h}}=\sum \mathrm{H}^{2} / \mathrm{r}-(\mathrm{Sh} . .)^{2 / \mathrm{rh}}$ & $\mathrm{M}_{\mathrm{h}}=\mathrm{S}_{\mathrm{h}} /(\mathrm{h}-1)$ \\
\hline Parents vs. Hybrids & 1 & $\mathrm{~S}_{\mathrm{kh}}=\mathrm{S}_{\mathrm{p}}-\mathrm{S}_{\mathrm{k}}-\mathrm{S}_{\mathrm{h}}$ & $\mathrm{M}_{\mathrm{kh}}=\mathrm{S}_{\mathrm{kh}}$ \\
\hline Error & $(\mathrm{r}-1)(\mathrm{p}-1)$ & $\mathrm{S}_{\mathrm{e}}=\mathrm{S}_{\mathrm{t}}-\mathrm{S}_{\mathrm{r}}-\mathrm{S}_{\mathrm{p}}$ & $\mathrm{M}_{\mathrm{e}}=\mathrm{S}_{\mathrm{e}} /(\mathrm{r}-1)(\mathrm{p}-1)$ \\
\hline Total & $\mathrm{rp}-1$ & $\mathrm{~S}_{\mathrm{t}}=\mathrm{S}_{\mathrm{xij}}{ }^{2}-(\mathrm{X} . .)^{2} / \mathrm{N}$ & \\
\hline
\end{tabular}

Where,

$r=$ number of replications

$\mathrm{p}=$ number of progenies

$\mathrm{N}=$ total number of observations $(\mathrm{r} \times \mathrm{p})$

$\mathrm{S}=$ summation

$\mathrm{R}=$ replication total

$\mathrm{P}=$ progeny total

$\mathrm{k}=$ number of parents

$\mathrm{h}=$ number of hybrids

$\mathrm{X} .$. = grand total of the observations 
Table.3 Analysis of variance for grain yield and other traits

\begin{tabular}{|c|c|c|c|c|c|c|c|c|}
\hline Source & d.f. & $\begin{array}{c}\text { Plant } \\
\text { height } \\
(\mathbf{c m})\end{array}$ & $\begin{array}{c}\text { Number of } \\
\text { effective } \\
\text { tillers/ } \\
\text { plant }\end{array}$ & $\begin{array}{c}\text { Spike } \\
\text { length } \\
\text { (cm) }\end{array}$ & $\begin{array}{c}\text { Number } \\
\text { of days to } \\
50 \% \\
\text { flowering }\end{array}$ & $\begin{array}{c}\text { Number } \\
\text { of } \\
\text { grains/ } \\
\text { Spike }\end{array}$ & $\begin{array}{c}\text { Number } \\
\text { of days to } \\
\text { maturity }\end{array}$ & $\begin{array}{l}\text { Grain } \\
\text { yield/ } \\
\text { plant } \\
\text { (g) }\end{array}$ \\
\hline Replications & 2 & 00.37 & 01.03 & 00.29 & $41.81^{* *}$ & 09.03 & $24.33^{* *}$ & $36.03 *$ \\
\hline Parents & 8 & $129.59 * *$ & 03.75 & $02.54 *$ & 21. & $34.50 * *$ & 61. & 09.00 \\
\hline Hybrids & 17 & $220.40^{* *}$ & $22.37 * *$ & $06.02 * *$ & $19.69^{* *}$ & $48.54 * *$ & $81.87 * *$ & $51.72^{* *}$ \\
\hline $\begin{array}{l}\text { Parents v/s } \\
\text { Hybrids }\end{array}$ & 1 & $4535.75^{* *}$ & $60.50^{* *}$ & $41.10^{* *}$ & 04.50 & $37.55^{*}$ & $4386.72 * *$ & $186.88^{* *}$ \\
\hline Error & 52 & 05.68 & 03.31 & 00.90 & 01.69 & 07.67 & 01.53 & \\
\hline
\end{tabular}

Table.4 Mean and range values for grain yield and other traits

\begin{tabular}{|c|c|c|c|c|c|c|c|}
\hline $\begin{array}{l}\text { PARENTS/ } \\
\text { HYBRIDS }\end{array}$ & $\begin{array}{l}\text { Plant } \\
\text { height } \\
\text { (cm) }\end{array}$ & 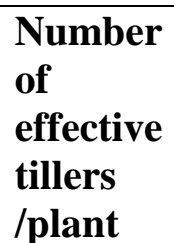 & $\begin{array}{l}\text { Spike } \\
\text { length } \\
\text { (cm) }\end{array}$ & $\begin{array}{l}\text { Number } \\
\text { of days to } \\
50 \% \\
\text { flowering }\end{array}$ & $\begin{array}{l}\text { Number } \\
\text { of } \\
\text { grains/ } \\
\text { spike }\end{array}$ & $\begin{array}{l}\text { Number } \\
\text { of days to } \\
\text { maturity }\end{array}$ & $\begin{array}{l}\text { Grain } \\
\text { yield / } \\
\text { plant (g) }\end{array}$ \\
\hline \multicolumn{8}{|l|}{ PARENTS } \\
\hline MEAN & 90.31 & 11.48 & 10.96 & 64.22 & 50.81 & 142.22 & 18.00 \\
\hline RANGE & $\begin{array}{l}79.73- \\
96.33\end{array}$ & $\begin{array}{l}10.33- \\
14.00\end{array}$ & $\begin{array}{l}09.97- \\
12.90\end{array}$ & $\begin{array}{l}61.00- \\
70.00\end{array}$ & $\begin{array}{l}45.33- \\
54.67\end{array}$ & $\begin{array}{l}135.00- \\
148.00\end{array}$ & $\begin{array}{l}15.00- \\
20.00\end{array}$ \\
\hline \multicolumn{8}{|l|}{ FEMALES } \\
\hline MEAN & 89.63 & 10.89 & 10.88 & 63.33 & 49.77 & 141.67 & 17.33 \\
\hline RANGE & $\begin{array}{l}79.73- \\
96.33\end{array}$ & $\begin{array}{l}10.33- \\
11.67\end{array}$ & $\begin{array}{l}10.47- \\
12.00\end{array}$ & $\begin{array}{l}61.00- \\
66.00\end{array}$ & $\begin{array}{l}45.33- \\
54.33\end{array}$ & $\begin{array}{l}135.00- \\
148.00\end{array}$ & $\begin{array}{l}15.00- \\
20.00\end{array}$ \\
\hline \multicolumn{8}{|l|}{ MALES } \\
\hline MEAN & 91.67 & 12.67 & 11.11 & 66.00 & 52.89 & 143.33 & 19.33 \\
\hline RANGE & $\begin{array}{l}86.00- \\
95.00\end{array}$ & $\begin{array}{l}12.00- \\
14.00\end{array}$ & $\begin{array}{l}09.97- \\
12.90\end{array}$ & $\begin{array}{l}63.00- \\
70.00\end{array}$ & $\begin{array}{l}50.00- \\
54.67\end{array}$ & $\begin{array}{l}135.00- \\
150.00\end{array}$ & $\begin{array}{l}19.00- \\
20.00\end{array}$ \\
\hline \multicolumn{8}{|l|}{ HYBRIDS } \\
\hline MEAN & 74.43 & 10.09 & 12.47 & 64.72 & 49.27 & 126.94 & 14.78 \\
\hline RANGE & $49.67-84$ & $\begin{array}{l}07.00- \\
16.67\end{array}$ & $\begin{array}{l}09.27- \\
14.17\end{array}$ & $\begin{array}{l}60.00- \\
70.00 \\
\end{array}$ & $\begin{array}{l}44.33- \\
56.67\end{array}$ & $\begin{array}{l}115.00- \\
137.00\end{array}$ & $\begin{array}{l}10.00- \\
23.00 \\
\end{array}$ \\
\hline
\end{tabular}

To get maximum yield associated with best combinations of other peripheral traits is the aim of any breeding programs. Further, the use of heterosis for getting high yield with improved quality has been largely used in cross-pollinated crops, but in self-pollinated crops also evidences are available to confirm the potential use of heterosis (Haq and Laila, 1991). Analysis of variances and means for yield and most of the yield contributing traits revealed the presence of highly significant effect of parents, crosses and parent's $\mathrm{v} / \mathrm{s}$ crosses except for days to $50 \%$ flowering in parent's $\mathrm{v} / \mathrm{s}$ hybrids, number of effective tillers and grain yield per plant in parents. The significant variations due to parents for all the traits studied indicate that parents possess good amount of genetic variability. The 
variance due to hybrids was also significant for all the traits studied suggesting the generation of good amount of variability among the hybrids and also the possibilities of identifying the superior hybrids from the study. Comparison of means of hybrids with mean of parents as a group was found to be significant for most of the traits which suggested that the hybrids differ considerably from the parents for most of the traits and also the existence of substantial heterosis for the traits studied. The results revealed that the variances due to parents, hybrids and parents v/s hybrids were significant. The parent with the minimum plant height was DWR 19 $(79.73 \mathrm{~cm}$.$) , maximum number of effective$ tillers per plant was DPW 621-50 (14 tillers), minimum days to $50 \%$ flowering was DWR 41 at 61 days, maximum grains per spike was PBW 550 (54.67) and minimum days to maturity were DWR 46 and PBW 550 at 135 days. Amongst the crosses, minimum plant height was observed in DWR 46 x RSP $561(49.67 \mathrm{~cm})$, maximum number of tillers was IBWSN1175 x PBW 550 with 16.67 tillers, maximum spike length with IBWSN1175 x RSP 561 and DWR $19 \times$ RSP 561 had spike length measuring $14.17 \mathrm{~cm}$, minimum days to $50 \%$ flowering were IBWSN1047 x PBW 550 and DWR 41 x RSP 561 with 60 days, maximum value for this trait were IBWSN1175 x PBW 550 (56.67), maximum grain yield per plant was IBWSN1175 x PBW 550.

\section{References}

Angus, W.J. and Fenwick, P.M. 2008. Using genetic resistance to combat pest and disease threats. In: Arable cropping in a changing climate. HGCA conference, 23-24 January, 2008. pp. 21-27

Bariana, H.S and McIntosh, R.A. 1993. Cytogenetic studies in wheat. XV. Location of rust resistance genes in VPM1 and their genetic linkage with other disease resistance genes in chromosome 2A. Genome, 36: 476482.

Chen, X.M. and Line, R.F. 1995. Gene action in wheat cultivars for durable, hightemperature, adult-plant resistance and interaction with race-specific, seedling resistance to Puccinia striiformis. Phytopathol., 85: 567-572.

Haq, I. and Laila. 1991. Diallel analysis of grain and other agronomic traits in durum wheat. RACHIS, Barley Wheat Newslett., 10: 8-12.

Hart, G.E., Gale, M.D. and McIntosh, R.A. 1993. Linkage maps of Triticum Aestivum (hexaploid wheat, $2 \mathrm{n}=42$, genomes $\mathrm{A}, \mathrm{B}$ and $\mathrm{D})$ and $T$. tauschii $(2 \mathrm{n}=14$, genome D). In Genetic maps: Locus maps of complex genomes. Edited by S.J. O'Brien. Cold Spring Harbor Laboratory Press, Cold Spring Harbor, N.Y. pp. 6204-6219.

McIntosh, R.A. and Arts, C.J. 1995. Genetic linkage of the Yr1 and Pm4 genes for stripe rust and powdery mildew resistances in wheat. Euphytica, 89: 401-403.

Payne, P.I., Holt, L.M., Johnson, R. and Snape, J.W. 1989. Linkage mapping of four gene loci, Glu-B1, Gli-B1, Rg1 and Yr10 on chromosome 1B of bread wheat. Genetica Agraria, 40: 231-242.

\section{How to cite this article:}

Sandeep Kumar Bangarwa and Tuhina Dey. 2017. Grain Yield and Morpho-Physiological Traits in Stripe Rust Resistant Lines of Wheat (Triticum Aestivum L.). Int.J.Curr.Microbiol.App.Sci. 6(6): 811-816. doi: https://doi.org/10.20546/ijcmas.2017.606.095 